\title{
Biochemical Study on Some Important Markers in Human Milk
}

\author{
Ramadan A. Sayed*, Tahia H. Seleem*, Thoria S. Eldeeb*, \\ Moustafa A. Abdella** and Aida A. Mahmoud*** \\ * Department of Biochemistry, Faculty of medicine, Assiut University; \\ ** Department of Obstetrics and Gynecology, Faculty of Medicine, \\ Sohag University; ***Department of Biochemistry, Faculty of \\ Medicine, Sohag university
}

\begin{abstract}
Human milk offers the infants nutrients with high bioavailability as well as a large number of bioactive components such as lactoferrin, lysozyme and xanthine oxidase enzyme that confer immune and non immune protection against pathogens in the infant's environment. The objective of the present study was to evaluate the changes that occur in the levels of lactoferrin, lysozyme and xanthine oxidase enzyme in the different stages of human milk and to perform correlation between the levels of these protective factors in each stage of human milk and between the level of each and both the age and parity of the mothers. The present study included 80 women divided into 3 groups, Group I: 25 mothers provided colostrum, Group II: 25 mothers provided transitional milk and Group III: 30 mothers provided mature milk. The levels of lactoferrin and lysozyme and the activity of xanthine oxidase enzyme were measured. Lactoferrin level and xanthine oxidase enzyme activity were significantly lower in transitional milk and mature milk than in colostrum $(P<0.0001)$ and lower in mature milk than in transitional milk $(P<0.01$ and $P<0.001)$ respectively. On the other hand, the level of lysozyme was significantly lower in transitional milk than in colostrum $(P<0.01)$ but there is no significant difference between mature milk and either transitional milk or colostrum. There is no correlation between the levels of these parameters and either the age or the parity of the mothers in the different stages of human milk. There is significant positive correlation between lysozyme and lactoferrin in group I $(r=$ $0.52, P<0.01)$ and xanthine oxidase in group III $(r=0.44, P<0.05)$. On the other hand, there was significant negative correlation between lysozyme and lactoferrin in group II $(r=0.55, P<0.01)$. In conclusion, human's milk and colostrum contains important bioactive and protective agents that improve the infant's health.
\end{abstract}

\section{INTRODUCTION}

Infant depends on maternal transfer of nutrients, bioactive components and protective agents both before and after birth. Human milk, like the milk of many other mammals, is specifically adapted to the need of the newborn.

A variety of protective factors in human milk are claimed to be responsible for the antibacterial properties of human milk. Kwon bacterial growth inhibiting factors in 
human milk are lysozyme and lactoferrin ${ }^{1}$. Lactoferrin, an ironbinding glycoprotein, was first isolated from cow milk and subsequently from human milk. It has many proposed biological functions, including antibacterial/antiinflammatory activities, defense against gastrointestinal infections, participation in local secretory immune systems in synergism with some immunoglobulins and other protective proteins ${ }^{2}$.

Lysozyme is an acid and heat stable enzyme that is abundant in the breast milk and in most other mucosal body fluids ${ }^{3}$. It lyses mostly gram positive and few gram negative bacteria or induces their aggregation and it possesses prominent antiinflammatory properties ${ }^{4}$.

Lactoferrin and lysozyme are now considered as major components of innate immunity, which might play an important role in first-line epithelial defenses should be transferred passively from milk to child $^{5}$

Xanthine oxidase is an enzyme present in intestine, liver milk and to lesser degree in almost mammalian tissues. The enzyme catalyzes the oxidation of hypoxanthine to xanthine and the later to uric acid, although it has a low substrate specificity, oxidizing, also, several proteins and aldhydes at a lower rate ${ }^{6}$.

Recently Stevens et al. ${ }^{7}$ discovered a completely new aspect of the enzyme activity, that this enzyme which is a naturally occurring component of milk that has a protective action in the baby's stomach. The antibacterial effect of human milk xanthine oxidase is due to the fact that xanthine oxidase is a cellular redox enzyme and can generate nitric oxide in the baby's stomach, which is a well known microbicidal species ${ }^{7}$.

The aim of the present work is to perform a cross sectional study of the changes that occur in the levels of lactoferrin, lysozyme and xanthine oxidase in the different stages of human milk (colostrum, transitional milk and mature milk) during long term lactation ( $<15$ months), and perform correlation between the levels of these protective factors in each stage of human milk and between the level of each and both the age and parity of the mothers. Also, to support the recommendations that breast milk is the best food for infants and the breast-feeding should be started immediately postpartum.

\section{SUBJECTS \& MESTHODS}

\section{(I) Subjects:}

The present study included 80 postpartum women, who delivered and were nursing a single baby at different stages of lactation. They are divided into 3 groups:

(1) Group I: (25 women) provided colostrum at 1-5 days postpartum.

(2) Group II: (25 women) provided transitional milk at 6-14 days postpartum.

(3) Group III: (30 women) provided mature milk at 15 days - 15 months postpartum.

Women studied were free from medical and infectious diseases and their infants were healthy. They were from 18 to 45 years of age was (mean \pm SD $29.6 \pm 6$ ) and their parity ranged from one to ten (mean $\pm \mathrm{SD} 4 \pm 2$ ). 
Group I and II mothers were recruited from the Department of Obstetrics and Gynecology in Sohag University Hospital; they were coming for delivery or medical consultance.

Group III mothers were recruited from the Maternity Care Units in Sohag. Consent was obtained from each mother before the study.

The characterization of human milk as colostrum, transitional or mature was according to Behram et al. ${ }^{\mathbf{8}}$.

\section{Milk Samples:}

Milk samples were taken 3 hours after the last nursing according to Goldman et al, ${ }^{62}$. From either breast by a sterilized manual breast pump each milk sample was divided into 2 aliquots, one aliquot was centrifuged at $5000 \mathrm{x} \mathrm{g}$ at $4^{\circ} \mathrm{C}$ for ten minutes to obtain an aqueous fraction, a membrane layer and a lipid layer. The membrane and lipid layers were separated and removed, the aqueous fraction which was stored al $-20^{\circ} \mathrm{C}$ till analyzed for its lactoferrin and lysozyme content. The second aliquot was centrifuged at $5000 \mathrm{x} \mathrm{g}$ for ten minutes after addition of $1 \%$ triton $\mathrm{X}$ 100 (to separate xanthine oxidase from the fat globule membrane). The aqueous part stored at -20 "C till used for determination of xanthine oxidase activity ${ }^{9,10 \& 11}$.

\section{(II) Methods:}

\section{1- Assay for lactoferrin content}

Lactoferrin was measured using kit supplied by oxis International, Inc. (Bioxytech (B) lactof Enzyme immunoassay Catalog No. 210115).

\section{2- Assay for lysozyme content}

Lysozyme activity was measured as suggested by Shugar $(1952)^{\mathbf{1 2}}$. The rate of lysis of Micrococcus lysodeikticus cells is determined. One unit is equal to a decrease in turbidity per 0.001 minute at $450 \mathrm{~nm}$ at $\mathrm{pH} 7$ and $25^{\circ} \mathrm{C}$ under the specified conditions.

\section{3- Assay for Xanthine oxidase activity}

Xanthine oxidase activity is determined by measuring the rate of formation of urate from hypoxanthine. A unit of activity is that forming one micromole of urate per minute at $25^{\circ} \mathrm{C}^{13}$.

Determination of uric acid was by uric acid liquicolor test (PAPMethod), a kit supplied by Human, which is an enzymatic colorimetric test with lipid clearing factor, Ca No 10690 .

\section{RESULTS}

\section{I- Lactoferrin levels:}

The current results revealed that lactoferrin levels in colostrum (group I) ranged from $1.6 \mathrm{mg} / \mathrm{ml}$ to $3.97 \mathrm{mg} / \mathrm{ml}$, with a mean \pm S.D $2.794 \pm 0.685$ $\mathrm{mg} / \mathrm{ml}$. In transitional milk, (group II) it ranged from $0.71 \mathrm{mg} / \mathrm{ml}$ to 1.55 $\mathrm{mg} / \mathrm{ml}$, with a mean \pm S.D $0.959 \pm$ $0.158 \mathrm{mg} / \mathrm{ml}$. In mature milk, (group III) lactoferrin levels ranged from 0.64 $\mathrm{mg} / \mathrm{ml}$ to $0.96 \mathrm{mg} / \mathrm{ml}$, with a mean + S.D $0.856 \pm 0.13 \mathrm{mg} \mathrm{ml}$.

Lactoferrin levels in colostrum were significantly higher than in transitional milk and mature milk $\{\mathrm{P}$ $<0.0001)$ and in transitional milk, lactoferrin levels were significantly higher than in mature milk $(\mathrm{P}<0.01)$, tables (1 and 2).

\section{2- lysozyme levels:}

The present results showed that lysozyme levels in colostrum (group I) ranged from $61.6 \mu \mathrm{g} / \mathrm{ml}$ to 404 
$\mu \mathrm{g} / \mathrm{ml}$ with mean \pm S.D $112 \pm 76.88$ $\mu \mathrm{g} / \mathrm{ml}$, in transitional milk (group II) ranged from $14 \mu \mathrm{g} / \mathrm{ml}$ to $158 \mu \mathrm{g} / \mathrm{ml}$, with a mean \pm S.D $666 \pm 40.41 \mu \mathrm{g} / \mathrm{ml}$ and in mature milk, (group III) lysozyme levels ranged from $114 \mu \mathrm{g} / \mathrm{ml}$ to $290 \mu \mathrm{g} / \mathrm{ml}$, with a mean \pm S.D 101 . $82 \pm 79.69 \mu \mathrm{g} / \mathrm{ml}$.

Lysozyme levels were significantly higher in colostrums than in transitional milk $(\mathrm{P}<0.01)$, but in mature milk, lysozyme levels were similar to those in colostrum $(\mathrm{P}>$ 0.05 ) tables ( 1 and 2 ).

3-Xanthine oxidase enzyme activity levels:

Xanthine oxidase activity levels in colostrum (group I) ranged from 0.21 $\mathrm{mU} / \mathrm{ml}$ to $9.19 \mathrm{mU} / \mathrm{ml}$, with a mean + S.D $3.713+2.574 \mathrm{mU} / \mathrm{ml}$, in transitional milk (group II) ranged from $(0.2 \mathrm{mU} / \mathrm{ml}$ to $4.8 \mathrm{mU} / \mathrm{ml})$, with a mean + S.D $(0.976+1.067 \mathrm{mU} / \mathrm{ml}$ and in mature milk (group III) ranged from 0.021 to $0.58 \mathrm{mU} / \mathrm{ml}$ with mean + S.D $(0.266+0.21 \mathrm{ml} \mathrm{ml}$.

Xanthine oxidase activity levels were significantly higher in colostrum than in transitional milk $(\mathrm{P}<0.0001)$ and higher in transitional milk than in mature milk $(\mathrm{P}<0.001)$, tables $(1$ and 2).

\section{Correlation study:}

The present result showed that:

\section{(1) Group I:}

There was significant positive correlation between lysozyme and lactoferrin $(\mathrm{r}=0.518, \mathrm{P}<0.01)$. However, there was insignificant correlation between xanthine oxidase and lysozyme and between xanthine oxidase and lactoferrin table (3).

Correlation between lactoferrin levels and age of the mothers was insignificant and so correlation between lactoferrin level and parity of the mothers. Also, correlation between lysozyme levels and both the age and parity of the mothers was insignificant and correlation between xanthine oxidase activities and both age and parity of mothers was insignificant table (4).

\section{(2) Group II:}

There was significant negative correlation between lysozyme and lactoferrin $(\mathrm{r}=-0.553, \mathrm{P}<0.05)$. There was insignificant correlation between xanthine oxidase and lactoferrin and xanthine oxidase and lysozyme table (3).

Correlation between lactoferrin levels and both the age and parity of mothers was insignificant. Also, the correlation between lysozyme level and xanthine oxidase activities and both the age and parity of mothers was insignificant table (4).

\section{(3) Group III:}

There was significant positive correlation between lysozyme and xanthine oxidase $(\mathrm{r}=0.443, \mathrm{P}<0.05)$. However, there was insignificant correlation between lysozyme and lactoferrin and xanthine oxidase and lysozyme table (3).

Correlation between the levels of lactoferrin, lysozyme and xanthine oxidase and both the age and parity of the mothers were insignificant table (4). 
Table (1): Levels of lactoferrin, lysozyme and xanthine oxidase in colostrums (group I), transitional milk (group II) and mature milk (group III).

\begin{tabular}{|l|l|l|l|}
\hline & Group I & Group II & Group III \\
\hline Lactoferrin (mg/ml) & $2.794 \pm 0.685$ & $0.959 \pm 0.158$ & $0.856 \pm 0.13$ \\
& $(1.6-3.97)$ & $(0.71-1.55)$ & $(0.64-0.96)$ \\
& $\mathrm{N}=25$ & $\mathbf{N}=\mathbf{2 5}$ & $\mathrm{N}=30$ \\
\hline Lysozyme ( $\mu \mathbf{g} / \mathbf{m l})$ & $112 \pm 0.685$ & $66 \pm 40.41$ & $101.82 \pm 79.69$ \\
& $(61.6-404)$ & $(14-158)$ & $(114-290)$ \\
& $\mathrm{N}=25$ & $\mathrm{~N}=25$ & $\mathrm{~N}=30$ \\
\hline Xanthine oxidase (mU/ml) & $3.713 \pm 2.574$ & $0.976 \pm 1.067$ & $0.266 \pm 0.21$ \\
& $(0.21-9.19)$ & $(0.2-4.8)$ & $(0.021-0.58)$ \\
& $\mathrm{N}=25$ & $\mathrm{~N}=25$ & $\mathrm{~N}=30$ \\
\hline
\end{tabular}

Values without brackets are mean $\pm S D$

Values with brackets are range

$N$ means number

Table (2): Level of significant difference between lactoferrin, lysozyme and xanthine oxidase in colostrums (group I), transitional milk (group II) and mature milk (group III).

\begin{tabular}{|l|l|l|l|}
\hline & Group I/Group II & Group I/Group III & Group II/Group III \\
\hline Lactoferrin & $\mathrm{P}<0.0001^{* * *}$ & $\mathrm{P}<0.0001^{* * *}$ & $\mathrm{P}<0.01^{*}$ \\
\hline Lysozyme & $\mathrm{P}<0.01^{*}$ & $\mathrm{P}>0.05(\mathrm{~ns})$ & $\mathrm{P}>0.05(\mathrm{~ns})$ \\
\hline Xanthine oxidase & $\mathrm{P}<0.0001^{* * *}$ & $\mathrm{P}<0.0001^{* * *}$ & $\mathrm{P}<0.001^{* *}$ \\
\hline
\end{tabular}

$P$ means level of significance

ns means non significant

Table (3): Correlation between lactoferrin, lysozyme and xanthine oxidase in colostrums (group I), transitional milk (group II) and mature milk (group III).

\begin{tabular}{|c|c|c|}
\hline \multicolumn{3}{|c|}{ Colostrums (group I) } \\
\hline Variable & Lactoferrin & Lysozyme \\
\hline Lysozyme & $\begin{array}{l}(0.518) \\
<0.01^{*}\end{array}$ & \\
\hline Xanthine oxidase & $\begin{array}{l}\text { (0.125) } \\
\text { ns }\end{array}$ & $\begin{array}{l}(0.292) \\
\text { ns }\end{array}$ \\
\hline \multicolumn{3}{|c|}{ Transitional milk (group II) } \\
\hline Variable & Lactoferrin & Lysozyme \\
\hline Lysozyme & $\begin{array}{l}(-0.553) \\
<0.01 *\end{array}$ & \\
\hline Xanthine oxidase & $\begin{array}{l}(0.144) \\
\text { ns }\end{array}$ & $\begin{array}{l}(0.233) \\
\text { ns }\end{array}$ \\
\hline \multicolumn{3}{|c|}{ Mature milk (group III). } \\
\hline Variable & Lactoferrin & Lysozyme \\
\hline Lysozyme & $\begin{array}{l}(-0.144) \\
\text { ns }\end{array}$ & \\
\hline Xanthine oxidase & $\begin{array}{l}(0.313) \\
\text { ns }\end{array}$ & $\begin{array}{l}(0.443) \\
<0.05^{*}\end{array}$ \\
\hline
\end{tabular}

Values without brackets are level of significance $(P)$

Values with brackets are correlation coefficients (r)

ns means non significant 
Table (4): Correlation between lactoferrin, lysozyme and xanthine oxidase in colostrums (group I), transitional milk (group II) and mature milk (group III) and age and parity of mothers.

\begin{tabular}{|l|l|l|l|}
\hline Colostrums (group I) & Lactoferrin & Lysozyme & Xanthine oxidase \\
\hline Variable & $(-0.02)$ & $\begin{array}{l}(-0.03) \\
\text { ns }\end{array}$ & $\begin{array}{l}(0.06) \\
\text { ns }\end{array}$ \\
\hline ns & $\begin{array}{l}(-0.01) \\
\text { ns }\end{array}$ & $\begin{array}{l}(-0.11) \\
\text { ns }\end{array}$ & $\begin{array}{l}(0.14) \\
\text { ns }\end{array}$ \\
\hline Parity & Lactoferrin & Lysozyme & Xanthine oxidase \\
\hline Transitional milk (group II) & $\begin{array}{l}(-0.14) \\
\text { ns }\end{array}$ & $\begin{array}{l}(0.14) \\
\text { ns }\end{array}$ \\
\hline Variable & $(-0.13)$ & $(-0.01)$ & $(0.12)$ \\
Age & ns & ns \\
\hline Parity & $(-0.16)$ & Lysozyme & Xanthine oxidase \\
& ns & $(-0.05)$ & $(0.12)$ \\
Mature milk (group & III). & ns \\
\hline Variable & Lactoferrin & $(-0.18)$ & ns \\
\hline Age & $(-0.21)$ & ns & \multicolumn{2}{l|}{} \\
\hline Parity & $(-0.12)$ & ns &
\end{tabular}

Values with brackets are correlation coefficients ( $r$ )

ns means non significant

\section{DISCUSSION}

Breast milk is the natural food for full term infants during the first months of life. It is always readily available at the proper temperature and needs no time for preparation. The milk is fresh and free from contaminating bacteria which reduces the chances of gastrointestinal disturbances ${ }^{8}$. Colostrum is the secretion of the breasts during the latter part of pregnancy and for the 24 days after delivery. Transitional milk: secreted after the first few days of lactation (6 - 14 days postpartum). Mature milk: secreted by the $3^{\text {rd }}$ or $4^{\text {th }}$ weeks and lasts for 15 months ${ }^{8}$.
Some molecules and cells in human milk actively help infants stave off infection. These molecules and cells help to prevent micro-organism from penetrating the body's tissues. Some of the molecules bind to microbes in the lumen of the gastrointestinal tract. Other molecules lessen the supply of particular minerals and vitamins that harmful bacteria need to survive in the digestive tract. Certain immune cells in human milk are phagocytes that attack microbes directly. Another set produces chemicals that invigorate the infant's own immune response ${ }^{\mathbf{1 4}}$.

Goldman et al. ${ }^{15}$, suggested that human milk protects the infant not only by providing anti-infective 
agents but also by minimizing inflammation.

Also, feeding of human milk to premature infants not only provides the infants with immune factors (such as IgA, lactoferrin and lysozyme), but might in addition enhance the endogenous synthesis of these agents by the infant ${ }^{16}$.

Lactoferrin is an iron-binding glycoprotein of the transferrin family ${ }^{17}$. The name lactoferrin is derived from its affinity to bind iron. Lactoferrin binds iron over a hundred fold more strongly than transferrin ${ }^{\mathbf{1 8}}$.

Lactoferrin is predominantly found in the products of the exocrine glands located in the gateways of the digestive, respiratory and reproductive system, suggesting a role in the nonspecific defense against invading pathogens ${ }^{19}$.

Lactoferrin may, also, be found in blood. Plasma lactoferrin is derived from the neutrophils, which degranulate and synthesize Lactoferrin during inflammation ${ }^{20,21}$.

Lactoferrins are single chain polypeptides of about $80,000 \mathrm{Da}$ containing 1-4 glycans depending on the species ${ }^{22}$.

The biological actions of lactoferrin are wide ranging and include inhibition of the survival or growth of many different pathogenic organisms; activation or stimulation of a variety of immune system cells; regulation of normal cell growth and inhibition of abnormal tumor growth and spread of cancer cells in laboratory animals ${ }^{\mathbf{1 8}}$.

The antimicrobial activity of lactoferrin has been attributed to iron binding by lactoferrin and a resulting iron deprivation of the inhibited microorganisms ${ }^{23}$. However, Feng et $a l^{24}$ showed that apolactoferrin (iron free lactoferrin) has greater antimicrobial activity than lactoferrin.

Green and Pastewka ${ }^{25}$ showed that prolactin stimulates the synthesis of lactoferrin from mouse mammary gland explants cultured in a synthetic medium containing insulin and hydrocortisone. Goldman et al. ${ }^{15}$ performed a longitudinal study of the immunologic actors in human milk during the first year of lactation. They found that the concentration of lactoferrin progressively decreased through the first eight weeks but not thereafter. Houghton et al. measured lactoferrin in breast milk from Aboriginal and non-Aboriginal Australian women using an enzyme immunoassay. They found that lactoferrin concentrations were significantly higher in the first 15 days postpartum than in the period after the 15 days.

However, Reddy et al. ${ }^{26}$, Prentice et al. $^{27}$ and Montagne et al., ${ }^{28}$ - found lactoferrin concentration higher than ours, although the same pattern of lactoferrin content (high in colostrum and decrease after that in transitional and mature milk) existed in their studies. The differences in these measured levels of lactoferrin may be due to differences in the methods and standards, which were used. Reddy et $a .^{26}$ and Pentice et al. ${ }^{27}$ used radial immunodiffusion while Montagne et $a l^{28}$ used nephelometric immuno assay.

The in vitro antimicrobial activity of lactoferrin has been known for many years, but there is only limited informations available on in vivo effects. Drescher et al. ${ }^{29}$ demonstrated 
a bacteriostatic effect for lactoferrin in the intestine of young pigs, Kakuka and Kurokua ${ }^{30}$ showed that lactoferrin had a protective effect against infection of red sea bream by $\mathrm{C}$. irritants.

In the present study, we reported lactoferrin concentrations in colostrum, transitional milk and mature milk. Lactoferrin concentrations were significantly higher in colostrum than in transitional milk $(\mathrm{P}<0.0001)$ and higher in transitional milk than in mature milk $(\mathrm{P}<0.01)$. We also found that lactoferrin after the initial decrease in transitional milk and then in mature milk, remain relatively constant during the period of mature milk.

The current results agree with Houghton et al. ${ }^{10}$, Goldman et al. ${ }^{15}$ and Hennart et al. ${ }^{31}$, who studied antimicrobial proteins in milk of Belgian mothers during the first postpartum week and in the milk of Zairian mothers during long-term lactation ( $\leq 18$ months). They found that the milk content of anti-microbial proteins remained fairly constant during long-term lactation and that the nutrition status of the mother has no direct influence on milk content of lysozyme or lactoferrin. However, they found that a deficient nutritious status together with other factors seem to exert a negative indirect influence on the amount of antimicrobial proteins fed daily to infants by reducing milk yield. Also, they studied the relation between serum prolactin and the milk content of antimicrobial proteins. They found that mothers of parity one and two produced the highest levels of these protective factors and that infant's intake of these protective factors decreased in early lactation except for lysozyme, but infants 1-2 years still received substantial amounts of protective factors.

Montagne et $a^{28}$ used microparticle enhanced nephelometric immunoassay to study the dynamics of the major immunologic and nutritional proteins in early lactation in preterm and term milks over the first 2 weeks of lactation. They found that the lactoferrin concentration is higher in both term and preterm milk in the first 4 days after delivery and it is higher in preterm than in term milk. The authors owed the alterations in preterm milk to the immaturity of the mammary gland at premature delivery. This hypothesis sustained by their observation of higher concentration of serum albumin in early milk collected from primiparous mothers delivered before 33 weeks, which could results from the incomplete closure of tight junctions, allowing plasmatic molecules to diffuse into milk ${ }^{28}$.

Collectively, all the previous studies reported higher lactoferrin concentrations in colostrum than in transitional and mature milk. Filteau et $a .^{32}$ measured $\mathrm{Na}: \mathrm{K}$ ratio and immune factors (lactoferrin. lysozyme and $\lg \mathrm{A}$ ) in milk samples collected from wonen at 1-3 weeks postpartum and after 3 months. They found that the major contributors to milk immune factors concentration are mammary permeability (defined as an elevated $\mathrm{Na}: \mathrm{K}$ ratio) and individual variation. The increase in $\mathrm{Na}: \mathrm{K}$ ratio was associated with increase in all immune factors and $\mathrm{Na}$ : $\mathrm{K}$ ratio 
decreased as the days postpartum increased suggesting that this way partly normal physiologic changes as milk production adjusted to meat infant demand and as breast engorgement was received ${ }^{32}$.

Elevated milk sodium concentrations are characteristic of mastitis ${ }^{33}$ or breast engorgement ${ }^{34}$ poor suckling by the neonate infant may lead to breast engorgement, which increases the mammary gland permeability $^{32}$.

The composition of colostrum, with higher concentrations of sodium, chloride, and protein and lower concentrations of lactose, potassium and glucose is markedly different from that of mature milk. From permeability studies of the mammary epithelium in late pregnancy and at the onset of lactation in the goat, Linzell and Peaker ${ }^{35}$, have proposed that the composition of the colostrum could be due to the presence of a paracellular pathway across the mammary epithelium. In the goat, in late pregnancy, sucrose and lactose can readily pass between the milk and blood, but at parturition the mammary epithelium becomes impermeable to the disaccharides. Thus it would appear that a change in the form of the tight junctions is affected at about the time of parturition, effectively blocking the paracellular movements of lactose and ions ${ }^{\mathbf{3 6}}$.

Studies by Schanbacher et al. ${ }^{37}$ revealed that lactoferrin concentrations change during the mammary cycle. In the cow, the concentrations of lactoferrin and its messenger RNA especially increase during development of the mammary gland, colostrum formation and involution of the gland, whereas during lactation the levels of lactoferrin decrease, as opposed to the increasing levels of casien. The latter suggests that casien has primarily a nutritional function for the calf, whereas lactoferrin may have growth factor-like activity and protective functions for the non-lactating gland and the critical phase for the newborn just after birth ${ }^{19}$.

Lysozyme is an acid and heat stable enzyme that is abundant in breast milk and in most other mucosal body fluids ${ }^{3}$. Lysozyme of human milk is composed of 130 amino acid residues and has a molecular weight of $14,9 \mathrm{kDa}^{38}$. Lysozyme (muramidase) hydrolyzes preferentially the (beta) 1-4 glucosidic linkages between $\mathrm{N}$-acetyl murarnic acid and N-acetyl glucosamine of certain microorganisms, such as Micrococcus lysodeikticus. A somewhat more limited activity is exhibited towards chitin oligomers. In addition, lysozyme possesses prominent anti-inflammatory properties. Lysozyme has been shown to inhibit chemotaxis of activated leukocytes ${ }^{4}$. Other anti-inflammatory functions of lysozyme include inhibition of mitogen that induced lymphoblastogenesis and autologus mixed lymphocyte reaction ${ }^{63}$. Lysozyme has, also, been shown to inhibit the haemolytic activity of serum complement in a dose dependent fashion when tested within the levels present in normal and inflamed breast-milk samples, and other mucosal secretions ${ }^{4}$.

In the present study, we determined lysozyme activity and content in the different stages of 
human milk. Milk lysozyme levels were higher in colostrum than in transitional milk $(\mathrm{P}<0.01)$ and increase again in mature milk to reach levels similar to those in colostrum.

The current results are similar to those found by others using immunodiffusion techniques ${ }^{26,39,15}$ and to those found by Hennart et al. ${ }^{31}$, who used radio immunoassay. The same pattern of lysozyme content in the three stages of human milk was found by Montagne et al. ${ }^{40}$, who used nephelometric immunoassay method but the levels were higher than ours. This may be due to the difference is the method used.

Montagne et al. ${ }^{40}$ studied milk proteins during the first 3 months of lactation. They found that lysozyme concentration decreases after the first few days of lactation and increases again during the second month of lactation. They suggested that such increase could play a role as antiinfectious agents in the passive protection of infants during mature lactation and they may be involved in the protection of the mammary gland itself.

The independent developments of lysozyme and lactoferrin contents in breast milk during long-term lactation suggest that the production and/or the transfer of these two proteins are controlled by different mechanisms. Both proteins are closely associated in the cytoplasm of polymorphonuclear neutrophils. Lactoferrin is found in the secondary granules whereas lysozyme is found both in the primary and secondary granules. The plasma concentration of lysozyme is more closely related to the granulocyte turnover rate, whereas that of lactoferrin is related more to the total number of neutrophils in blood. Thus some differences likely exist in the release mechanisms of these intragranular proteins from neutrophils ${ }^{31}$.

Butte et $a .^{9}$ studied the daily ingestion of immunologic components in human milk during the first four months of life, they found that the absolute amounts of lysozyme secreted by the mammary gland and ingested on a weight basis by the infants rose between the first and fourth month. There are clues that suggest that lysozyme in human milk helps to maintain appropriate levels of that protein in the aero-alimentary tract of the breast - fed baby. First, there is some evidence that the production of lysozyme by epithelial cells of the tracheo - bronchial tree is lower in the newborn period as compared to later phases of infancy or adulthood. Also, the production of certain intestinal enzymes such as chymotrypsin and carboxypeptidase $\mathrm{B}$, which may degrade this protein, may be relatively low during early infancy. Furthermore the length and hence the surface area of the small intestine doubles in the first months of life. Thus, it seems plausible that the secretion of lysozyme by the mammary gland may be linked to the production and catabolism of that protein and the growth of the intestinal tract in early infancy ${ }^{9}$.

Xanthine oxidase is a widely distributed molybdoenzyme that in mammals is largely localized to epithelium and to capillary endothelial cells in a range of tissues ${ }^{41,42}$. The enzyme is a dimer of subunit molecular mass of about $150 \mathrm{kDa}$ 
containing four oxidation-reduction active cofactors, one FAD, one molybdopterin, and $2 \mathrm{Fe} / 2 \mathrm{~S}$ centers of the spinach ferredoxin type. Its generally accepted metabolic role is in purine catabolism, catalysing the oxidation of hypoxanthine to xanthine and of xanthine to uric acid ${ }^{\mathbf{1 1}}$.

Recently, the ability of xanthine oxidase (XO) to catalyze reactions that generate nitric oxide (NO) from inorganic nitrite was reported $\mathbf{4 3}$ and $\mathbf{4 4}$. $\mathrm{NO}$ is formed only under anaerobic conditions; when oxygen is present, superoxide is, also, produced, which reacts with Xanthine oxidase generated NO to form peroxynitrite ${ }^{45}$, a powerful bactericidal agent ${ }^{46}$.

An antibacterial role in the neonatal gut for XO-generated NO, and potentially peroxynitrite, is plausible for a number of reasons, both spatial and catalytic. $\mathrm{XO}$ is located on the outer surface of the milk fat globule membrane, and pathogenic bacteria, with the capacity to target epithelial membranes of the digestive tract, may well bind to similar antigens on the milk fat globule membrane, which is itself of epithelial cell origin ${ }^{47,48}$. This process will not only divert the bacteria from their primary target but will, also, bring them into intimate contact with XO. Contact of this type will be further promoted by the known affinity of $\mathrm{XO}$ for acidic polysaccharides $^{49}$, such as occur in many bacterial capsules ${ }^{50,}{ }^{51}$. Therefore, the local concentrations of $\mathrm{NO}$ and peroxynitrite produced in the vicinity of the bacteria could potentially be very high and could account for the antibacterial effects seen.
We used hypoxanthine as a reducing substance for assay of xanthine oxidase in human milk and colostrum. We measured the uric acid formed by uric acid liquicolor test. We found that xanthine oxidase activity is very high in colostrum compared to transitional and mature milk $(\mathrm{P}<0.0001)$ and high in transitional milk compared to mature milk $(\mathrm{P}<0.001)$.

These results are similar to those found by Zikakis et al. ${ }^{52}$, who used a radiometric method to assay milk samples taken, at widely varying stages of lactation from 59 donors and to those found by Brown et al., ${ }^{11}$ who used two methods for assay of xanthine oxidase activity in serial samples of breast milk taken from 14 donors (radiometric and fluorimetric assay).

Such levels are from one to two orders of magnitude less than those determined in fresh bovine milk, which nevertheless, appears to contain similar levels of xanthine oxidase protein ${ }^{\mathbf{1 1}}$. These observations further support the contention that the low activity of purified human milk xanthine oxidase towards xanthine or pterin is an intrinsic property of the human milk enzyme and not a preparation artifact ${ }^{53}$. Bradley and Gunther, ${ }^{54}$ noted similar results from milk samples of three mothers in which activity peaked at 3days postpartum, falling by up to $80 \%$ by day 7, while Zikakiz et al. ${ }^{53}$ observed that colostrum showed higher activity than did mature milk.

Xanthine oxidase enzyme activity showed no correlation with xanthine oxidase protein levels, which remained relatively constant. The 
consequence of these observations is that the true specific activity of xanthine oxidase is seen to vary dramatically with time. The most plausible explanation for the wide variation in xanthine oxidase activity levels is that they reflect posttranslational activation - de activation cycles 11. This demonstration of activation and deactivation in human milk xanthine oxidase may shed light on the question as to why an apparently inactive (to most reducing substrates apart from NADH) enzyme should occur in breast milk ${ }^{55}$. The high activity of xanthine oxidase in the early days postpartum strongly suggests a functional role for the enzyme in that period. Such role could involve bactericidal protection of the neonatal gut, as previously proposed ${ }^{56}$, 57. It is difficult to do other than speculae as to the factors initiating these changes in the molecular activity of milk xanthine oxidase, but response to hormonal variation is clearly a possibility. Levels of progesterone, estradiol and cortisol fall sharply postparum, while levels of prolactin rise, maximal changes occur around the $4^{\text {th }}$ or $5^{\text {th }}$ day after delivery 11.

The enzyme in other species, also, has been shown to undergo activation and deactivation at the molecular level but to a lesser extent than demonstrated in human milk. Itoh et al. ${ }^{58}$, reported that the specific activity of chicken liver xanthine dehydrogenase rose and fell again in response to raising and lowering the protein content of the chicken's diet, while Furth - walker and Amy ${ }^{59}$ showed similar activation of rat liver xanthine oxidase on exposure to a high protein diet.

Both groups of workers attributed these changes to variations in the content of inactive isoforms, known to make up $30-50 \%$ of the enzyme in each case. However, the properties of purified human milk xanthine oxidase suggest that, in this case the content of inactive enzyme could be more than $98 \%{ }^{55}$. The greater proportion of inactive xanthine oxidases and dehydrogenases is made up of "desulfo" enzyme in which the molybdenum atom is covalently double bonded to oxygen rather than to sulfur ${ }^{55,60}$.

In case of chicken liver xanthine dehydrogenase, Itoh et $a l^{58}$, proposed that the activation inactivation cycles reflected, specifically, interconversion of "desulfo" and "sulfo" forms of the enzyme.

Nishino and co-worker ${ }^{\mathbf{6 1}}$, demonstrated that the mitochondrial enzyme, rhondanese, could catalyse the reversible interconversion of "sulfo" and "desulfo" bovine milk xanthine oxidase in the presence of thiosulfate and sulfhydryl reagent.

Furth-Walker and Amy 59, similarly interpreted their data, obtained with rat liver, in terms of "desulfo" -"sulfo" enzyme conversion. In support of that interpretation, they showed that supplementation of the rat's diet with the sulfur-containing amino acid, methionine, was particularly effective in increasing the specific activity of xanthine oxidase in rat intestine. The apparent capacity of human milk xanthine oxidase to undergo activation-deactivation cycles, at the molecular level, has important implications for the role of 
xanthine oxidase in human tissue. Immunoaffinity purification of xanthine oxidase from human heart indicates that this enzyme has properties very like those of that from breast milk ${ }^{53}$ and it may well be that xanthine oxidases in many other human tissues are similar. These findings extend the possibilities for control of xanthine oxidase activity in vivo with consequent potential for the regulation of reactive oxygen species, known to be involved in both pathological and normal physiological processes.

In the present study, we found no correlation between either the age or parity of the mothers and the levels of lactoferrin, lysozyme and xanthine oxidase in the differents stages of human milk. These results agree with Hennart el al. ${ }^{31}$, who found no correlation between lactoferrin levels and parity of the mothers and with Montagne et $a .^{28}$, who found no significant effect of parity on the levels of milk proteins (lactoferrin, lysozyme, serum albumin , B-casien and SIgA), of term human milk. However, the present results disagree with the finding of Prentice et al. ${ }^{27}$ in which the ability to secrete what they collectively call "Protective factors" decreased with increasing parity and disagree with Houghton et al. ${ }^{\mathbf{1 0}}$, who studied the relation between lactoferrin concentration and parity of the mothers, they found that lactoferrin concentration increased with increasing parity. However, they found no correlation between the age of the mothers and lactoferrin concentration.

We studied the correlation between the variables in each group, we found that, there is significant positive correlation between lysozyme and lactoferrin in the stage of colostrum $(\mathrm{r}=0.518, \mathrm{P}<0.01)$, and there is significant positive correlation between lysozyme and xanthine oxidase in the stage of mature milk ( $\mathrm{r}$ $=0.443, \mathrm{P}<0.05)$, this agree with Prentice et $a .^{27}$, who found a strong positive interrelation between all the protective factors concentrations in the milk of each subject. However, there is significant negative correlation between lysozyme and lactoferrin in the stage of transitional milk $(r=-0.553 . P<0.01)$. This may be due to the sharp decrease in the level of lysozyme in the stage of transitional milk.

\section{REFERENCES}

1. Liepke, C. Zucht, H.D., Forssmann, W.G., Standker, L., (2001): Purification of novel peptide antibiotics from human milk J Chromatogr B Biomed Sci Appl; 752: 369-377.

2. Losnedahl, K.J., Hongwang, $M$ Veen Aslam, Zotr Sixiang, and Walter L. Hurley (1996): Antimicrobial factors in milk, Illinois Dairy report, University of Illinois, Research Report. At, WWW.Aces.Vive.

Edu/ansystem/dairy rep 96 Losnedahl.htmL.

3. Reitamo. S., Klockars, M., Adinolfi-M, and Osserman, EF. (1978): Human lysozyme (Origin and distribution in health and disease. Ric Clin Lab; 8:211-231.

4. Ogundele, M.O. (1998): A novel anti-inflammatory activity of lysozyme: Modulation of serum 
complement activation. Mediators of Inflammation; 7: 363-365.

5. Xanthou. M. Bines, J. and Walker, W.A. (1995): Human milk and intestinal host defence in newborns: an update $\mathrm{Adv}$. Pediatr., 42: 171 -208.

6. Morpeth, F.F. (1993): Studies on the specificity toward aldehyde substrates and steady-state kinetics of xanthine oxidase. Biochim Biophys Acta, 799:32834.

7. Stevens. CR, Millar, TM. Clinch, JG, Kanczler, JM, Bodameali, T. Blake. DR (2000): Antibacterial properties of xanthine oxidase in human milk Larcet 356 (9232): 829-30.

8. Behram, R.E., Kliegman, R.M., Jenson, H.B. (2000): Feeding of Infants and Children. Breast feeding Nelson textbook of pediatrics. Chapter 41(1)149-150.

9. Butte, N.F., Goldblum, R.M., Fehi, L.M., Loftin. K., Smith. e.O.. Garza. C. and Goldman. A.S. (1984): Daily ingestion of immunologic components in human milk during the first four months of life. Acta pediatr scand, 73: 296-301.

10. Huoghton. M.R., Gracey, M., Burke, V., Bottrell, C, and Spargo, R.M. (1985): Breast milk lactoferrin levels in relation to maternal nutritional status. J. Ped. Gastroenterol. and Nutrition, 4: 230-233.

11. Brown, A.M, Benboubetra, M., Ellison. U., Powell. D.. Reckles. J.D.. and Harrison, R. (1995): Molecular-activation-deactivation of xanthine oxidase in human milk. Biochim Biophys Acta; 1245; 245-248.

12. Shugar, D. (1952): Biochimica et Biophysica Acta, 8: 302-309.

13. Westerfield, W., Richert, D., and Haggins, E (1959): Further study with xanthine oxidase inhibitors J. Biol Chem 234: 1887.

14. Newman, J. (1995): How breast milk protects newborns. Scientific American 273: 76-79.

15. Goldman AS. Hanson SA and Hanson LA: (1987): Human Lactation Vol.3: The effect of human milk on the recipient infant. New York: Plenum press.

16. Schanler, R.J., Goldblum, RM, Garza, C, Goldman, AS. (1986): Enhanced fecal excretion of selected immune factors in very low birth weight infants fed fortified human milk. Pediatr. Res., 20: 711-4.

17. Lönnerdal, B. and Iyer, S., (1995): Lactoferrin: molecular structure and biological function. Annual Review of Nutrition 15: 93-110.

18. Kwait G: (1998): Lactoferrin. Nature's premier immuneBoosting protein. April/ May 1998, Vitamin Research Nutritional New.

19. Steijns JM and A.C.M. Van Hooijdonk; (2000): Occurrence, structure. biochemical properties and technological characteristics of lactoferrin. British Journal of Nutrition. 84 (Suppl. 1,): 511517.

20. Britigan, B.E., Serody, J. S. \& Cohen. M.S. (1994): The role of lactoferrin as an antiinflammatory molecule. 
Advances in experimental Medicine and Biology 397: 143 156.

21. Levay. P.F. \& Viljoen $\mathbf{M}$ (1995): Lactoferrin: a general review. Haematologica 80: 252267.

22. Spik, G, Coddeville, B, Bourne Y, Cambillaunt C \& Montreuil J. (1994): Primary and threedimensional structure of lactotransferrin (Lactoferrin) glycans. Advances in experimental Medicine and Biology 357: 21-32.

23. Reiter. B. (1985): The biological significance of the nonimmunoglobulin; protective proteins in milk. Development in Dairy chemistry 3: 281-336.

24. Feng, M., Vander Does, L. and Banties, A. (1995): Preparation of a prolactoferrin with a very iron saturation. J. Dairy Sci., 78: (11):2351-57.

25. Green, M.R. and Pastewka, J.V. (1978): Lactoferrin is a marker for prolactin response in mouse mammary explants. Endocrinology 103: 1510-12.

26. Reddy, V. Bhaskarm. C. Raghuramulu, N.. and Jagadeesan. V.. (1977): Antimicrobial factors in human milk. Acta pediatr scand, 66: 22932.

27. Prentice, A., Prentice, A.M., Cole, T.J., and whitehead, R.G. (1983): Determinants of variations in breast milk protective factor concentrations of rural Gambian mothers. Arch. Dis. Child, 58: 518-522.

28. Montagne, P.M., Cuilliere. M.L Mole, CM., Bene, M.C., and
Faure. $\quad$ G.C. (1999): Immunological and nutritional composition of human milk in relation to prematurity and mothers' parity during the first 2 weeks of lactation...J. Ped. Gastroenterol. Nutrition, 29: 7580.

29. Drescher, K., Roos, N., and Hagemeister. H. (1996): Biological activity and digestibility of lactoferrin. Deutsche Milchwischaft. 47, (7): 326- 327.

30. Kakuka, I. and Kurokura, $\mathbf{H}$. (1995): Defensive effect of orally administered bovine lactoferrin against cryptocaryon irritants infection of red sea bream. Fish pathology, 30: 289-90.

31. Hennart, P.F., Brasseur, D.J. Delogne-Desnoeck, J. Dramaix, M. and Robyn, C. (1991): Lysozyme, lactoferrin and secretory $\operatorname{IgA}$ content in breast milk: influence of duration of lactation, nutrition status, prolactin status and parity of mother. Am. J. clin. Nutr., 53: 329.

32. Filteau, S., Rice, A., Jennifer, J., Charkraborty, J., Stoltzfus, R., Francisco, A., and Willumsen, J., (1999): Breast milk immune factors in Bangladesh women supplemented postpartum with retinal or Bcarotene Am. J. Clin. Nutr., 69: 953-8.

33. Neville, M.C. Keller, R.P. Seact, J., Casey, C.E., and Archer, P. (1991): Studies on human lactation: milk volume and nutrient composition during 
weaning and lactogenesis Am. J. Clin. Nurt., 54: 81-92.

34. Prentice, A. and Prentice, A.M.. (1989): Unilateral breast dysfunction in lactating Gambian women. Ann. Trop Pediatr., 4: 19-23.

35. Linzell, J. and Peaker, $M$. (1974): Changes in colostrum composition and in the permeability of the mammary epithelium at about the time of parturition in the goat. J. Physiol., (London) 243: 129-151.

36. Hartman, P.E. and Prosser G.G.: (1989): Physiological basis of longitudinal changes in human milk yield and composition Federation proceeding 43. (9): 2448-2453.

37. Schanbacher, F.L., Talhouk, R.S and Murray, F.A. (1997): Biology and origin of bioactive peptides in milk. Livestock production. Science. 50: 105-123.

38. Hamosh, M, (1985): Human milk in colon, AR and Mohsen Z (eds): Pediatric pathophysiology, Boston. Little Browen \& Co. 1985. pp 69-85.

39. Mcclelland, D.B.L., MC Grath, J., and Samson, R.R. (1978): Antimicrobiol factors in human milk. Studies of concentration and transfer to the infant during the early stages of lactation. Acta pediatr. Scand., suppl 271: 3-20.

40. Montagne, P.M. Cuilliere. M.L. Mole, CM., Bene, M.C. and Faure, G.C. (2000): Dynamics of the main immunologically and nutritionally available proteins of human milk during lactation $\mathbf{J}$ Food composition and analysis, 13: 127-137.
41. Jarasch, E.D., Bruder, G. and Heid, H.W. (1996): Significance of xanthine oxidase in capillary endothelial cells. Acta Physiol Scand. 948 Suppl: 39-46.

42. Gossrau, R., Frederik, W.M. and Van Noorder, C.J.F. (1990): Histochemistry of reactive oxygen species (ROS) generating oxidases in cutaneous and mucous epithelia of laboratory rodents with special reference to xanththine oxidase. Histochemistry, 94(5): 539-544.

43. Godber, B.L.J., J. J. Doel, G. P. Sapkota, D. R. Blake, C. R. Stevens, R. Eisenthal, and $\mathbf{R}$. Harrison. (2000): Reduction of nitrite to nitric oxide catalysed by xanthine oxidoreductase. J. Biol. Chem., 275:7757-7763.

44. Millar, T. M., C. R. Stevens, N. Benjamin, R. Eisenthal, R. Harrison, and D. R. Blake. (1998): Xanthine oxidoreductase catalyses the reduction of nitrates and nitrite to nitric oxide under hypoxic conditions. FEBS (Lett). 427:225-228.

45. Godber, B.L. J., J. J. Doel, J. Durgan, R. Eisenthal, and R. Harrison. (2000): A new route to peroxynitrite: a role for xanthine oxidoreductase. FEBS (Lett). 475:93-96.

46. Brunelli, L., J.P. Crow, and J.S. Beckman (1995): The comparative toxicity of nitric oxide and peroxynitrite to Escherichia coli. Arch. Biochem. Biophys., 316:327-334.

47. Keenan, T.W., and S. Patton (1995): The structure of milk: implications for sampling and storage. A. The milk fat globule 
membrane, p. 5-50. In R. G. Jensen (ed.), Handbook of milk composition. Academic Press, New York, N.Y.

48. Patton, S., and T.W. Keenan. (1975): The milk fat globule membrane. Biochim. Biophys. Acta 415:273-309.

49. Adachi, T., T. Fukushima, Y. Usami, and K. Hirano. (1993): Binding of human xanthine oxidase to sulphated glycosylaminoglycans on the endothelial cell surface. Biochem. J., 289:523-527.

50. Jann, K., and B. Jann. (1997): Capsules of Escherichia coli,p. 113-143. In M. Sussman (ed.) Escherichia coli: mechanisms of virulence. Cambridge University Press, Cambridge, United Kingdom.

51. John T. Hancock, Robert Cherry, Catherine Hoare, Robert Eisenthal and Roger Harrison (2002). Antimicrobial properties of milk: dependence on presence of xanthine oxidase and nitrite. Antimicrob Agents Chemother., 46(10): 3308-3310.

52. Zikakis, J.P. Dougherty, T.M., and Baisotto, N.O. (1976): The presence and some properties of xanthine oxidase in human milk and colostrum. J. Food science, 41: 1408-12.

53. Abadeh, S., Case, P. and Harrison, R. (1993): Purification of xanthine oxidase from human heart, Biochem. Soc.Trans. 21: 995.

54. Bradley. P.L., and Gunther, $M$. (1960): The xanthine oxidase of human milk and colostrum. Biochem. J., 74. 150.
55. Abadeh. S., Killacky, J., Benboubetra, M. and Harrison, J. (1992). Purification and partial characterization of oxidase from human milk. Biochemical Biophys. Acta, 1117: 25-32.

56. Bjork, L., and Claesson, O., (1979): Role of xanthine oxidase in human milk. J. Dairy science, 62: 1221-15.

57. Moldoveanu, Z., Tenovuo. J. Mestecky. J. and Pruitt, K.M. (1982): Human milk peroxidase is derived from milk leukocytes. Biochim. Biophys. Acta 718: 103-8.

58. Itoh. R., Nishino. T., Usami, C, and Tsushima, K. (1978): An immunochemical study of the changes in chicken liver xanthine dehydrogenase activity during dietary adaptation. J. Biochem., 84: 19-26.

59. Furth-walker, D. and Amy, NK. (1987): Regulation of xanthine oxidase activity and immunologically detectable protein in rats in response to dietary protein and iron. J. Nutr., 117: 1697-1703.

60. Bray, R.C. (1975): In the enzyme (Boyer, P.D., ed) $3^{\text {rd }}$ End. Vol XII pp.299-419, Academic press. New York.

61. Nishino, T., Usami,C., and Tsushima, K. (1982): Reversible interconversion between sulfo and desulfo xanthine oxidase in a system containing rhodanese thiosulfate and sulfhydryl reagent Proc. Natl. Acad. Sci. (USA) 80: 1826-29.

62. Goldman AS., Garza C., Nichols B., and Goldblum RM (1982): Immunologic factors in 
human milk during first year of lactation. J pediatr; 100 (4):563-7.

63. Gordon, LI., Douglas, SD., Kay, NE. and Yamada, O. (1979):
Modulation of neutrophil function by lysozyme. Potential negative feedback system of inflammation. $\mathrm{J}$ clin invest. 64: 226-232.

\section{دراسة بيو كيميائية على بعض الدلالات الهامة في لبن الأم}

$$
\begin{aligned}
& \text { رضان عبد العال سيد" وتحبة هاشم سليم* و ثريا سعبي الديب* }
\end{aligned}
$$

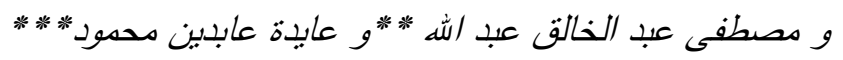

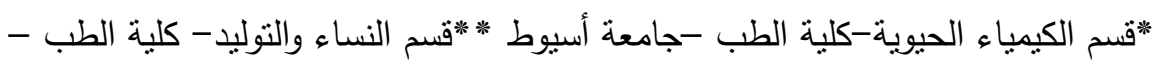

$$
\begin{aligned}
& \text { جامعة سوهاج **** قسم الكيمياء الحيوية-كلية الطب -جامعة سوهاج }
\end{aligned}
$$

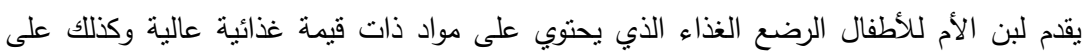

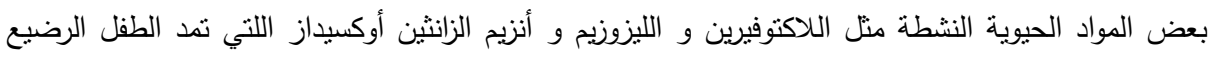

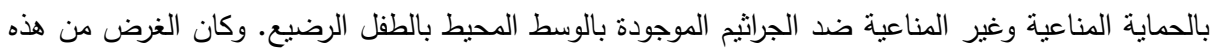

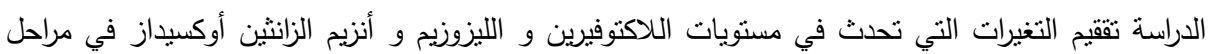
اللبن المختلفة المفرز من ثدي الأم. وكذللك دراسة العلاقة بين مستويات اللاكتوفيرين و الليزوزيم و أنزيم الزانثين

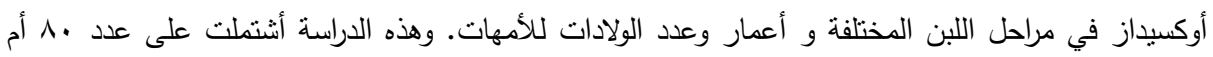

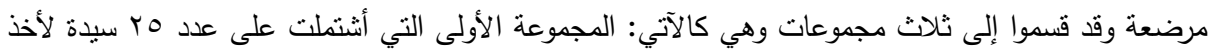
لبن السرسوب و المجموعة الثانية التي أثنملت على عدد بر سيدة لأخذ اللبن الأنتقالي و المجموعة الثالثة التي أثنتملت على عدد · r سيدة لأخذ اللبن الناضج وقد تم قياس مستويات اللاكتوفيرين و الليزوزيم و أنزيم الزانثين

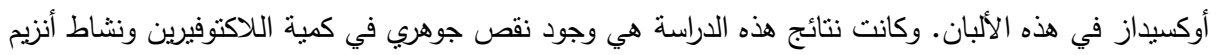

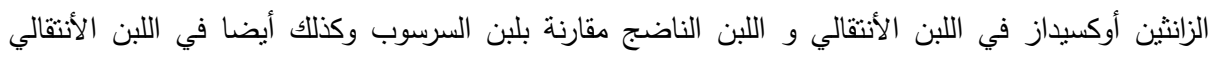
مقارنة باللبن الناضج. وفي المقابل وجد نقص جوهري في مستوى الليزوزيم في اللبن الأنتقالي مقارنة بلبن اللبن السرسوب ولكن لم يلاحظ أي تغيير جوهري بين اللبن الناضج وكل من اللبن الأنتقالي ولبن السرسوب. ولئ

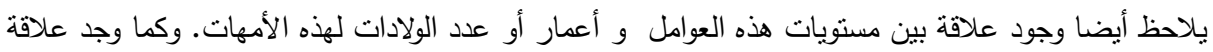

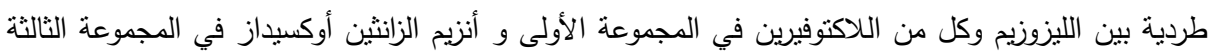

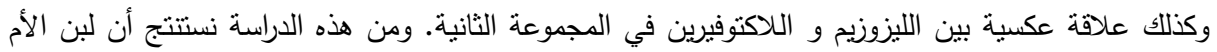

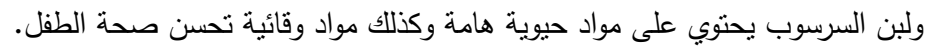

